Jurnal Keuangan dan Perbankan, 23(1):90-102 , 2019

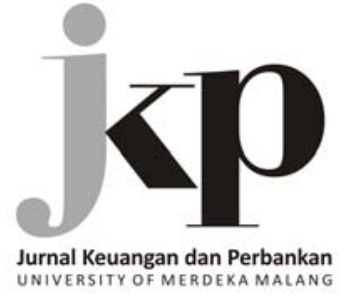

Article history:

Received: 2018-11-17

Revised: 2018-12-23

Accepted: 2019-01-15

Keywords:

Capital Structure; Pecking Order

Theory; Trade-off Theory

JEL Classification: C33, G02, G32

Kata Kunci:

Struktur Modal; Pecking Order

Theory; Trade-off Theory

$\triangle$ Corresponding Author:

Hotman Jefferson Simatupang:

Tel. +62 85791844387

E-mail: hotmanjefferson94@gmail.com

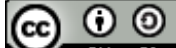

This is an open access

article under the CC-BY-SA license http://jurnal.unmer.ac.id/index.php/jkdp

\section{Determinants of capital structures based on the Pecking Order Theory and Trade-off Theory}

\section{Hotman Jefferson Simatupang, Lilik Purwanti, Endang Mardiati}

Master Program of Accounting, Faculty of Economy and Business, University of Brawijaya Jl. M.T. Haryono No.165 Malang, 65145, Indonesia

Abstract

Determining the decision of the company capital structure is a very important thing because it influences the development of resources potency and the sustainability of a company. Related to deciding on the capital structure, there is still different perception so far between pecking order theory and trade-off theory. This research aims to know the effect of profitability, sales growth, non-debt tax shield, the tangibility of assets, and funding surplus towards the capital structure of non-financial companies listed in Indonesia Stock Exchange (IDX) period 2014-2017. The research method used was CausalComparative Research with samples investigated were panel data of 154 non-financial companies experiencing funding surplus with total observation in the amount of 616 . The result of this research shows that non-debt tax shield and growth sales do not affect company capital structure. Besides that, funding surplus has a positive effect on the capital structure, while profitability and tangibility assets have a negative effect on the capital structure.

Abstrak

Penelitian ini bertujuan untuk mengetahui pengaruh antara profitabilitas, pertumbuhan penjualan, non debt tax shield, tangibility of asset, dan surplus pendanaan terhadap struktur modal pada perusahaan non keuangan yang terdaftar di Bursa Efek Indonesia (BEI) periode tahun 2014-2017. Metode penelitian yang digunakan adalah kausal komparatif (CausalComparative Research) dengan sampel yang diteliti yaitu 154 perusahaan non keuangan yang mengalami surplus pendanaan. Teknik pengambilan sampel yang digunakan yaitu purposive sampling. Hasil penelitian ini menunjukkan bahwa non-debt tax shield tidak berpengaruh terhadap struktur modal perusahaan. Selain itu, pertumbuhan penjualan, tangibility assets, dan surplus pendanaan memiliki pengaruh yang positif terhadap struktur modal, sedangkan profitabilitas memiliki pengaruh negatif terhadap struktur modal.

How to Cite : Simatupang, H. J., Purwanti, L., \& Mardiati, E. (2019). Determinants of capital structures based on the Pecking Order Theory and Trade-off Theory. Jurnal Keuangan dan Perbankan, 23(1), 90-102. https://doi.org/10.26905/jkdp.v23i1.2579 


\section{Determinants of capital structures based on the Pecking Order Theory and Trade-off Theory}

Hotman Jefferson Simatupang, Lilik Purwanti, \& Endang Mardiati

\section{Introduction}

The rapid economic development in the globalization era requires the company management to be careful in taking the decision related to the capital structure. The decision about the right capital structure can determine the best proportion between internal funding and external funding and minimize the bankruptcy risk. Two popular theories of the capital structure until now are pecking order theory and tradeoff theory. The different perspective of pecking order theory and trade-off theory until now still becomes debatable in the research related to the capital structure. Before 1999, the trade-off theory was still considered as the best theory in explaining the capital structure until there was much research on the capital structure focused on the usage of this theory. ShyamSunders \& Myers (1999) conducted the capital structure research which focused on pecking order theory and created the model to examine the funding of the company which experienced deficit and surplus of finance and found out the results that pecking order theory is the best theory to explain the capital structure. Frank \& Goyal (2000) found out the different result from the research by Shyam-Sunders \& Myers (1999). They found out that trade-off theory is the best theory in explaining the capital structure. Until now, there is much research conducted examination towards both of these theories and found out inconsistency among the research. According to Ross \& Westerfield (2008), in a trade-off theory, there is debt target which becomes a limitation for the company in conducting fund through debt and advantage like the decrease on the tax cost and capital cost through certain trade-off.

The company must be precise in determining the composition of the capital structure in accordance with the condition of the company finance. The research conducted by Haron (2016) found out the result that the capital structure decision of the Indonesian company consistently still follows pecking order theory and trade-off theory. Both of these theories have the opposite direction in the point of view related to decid- ing on the capital structure. Until now, there is much research conducted examination towards these two theories and found out inconsistency among the research results. According to Ross \& Westerfield (2008), in a trade-off theory, there is debt target which becomes the company limitation in conducting the funding through debt and the advantage such as the decrease on tax cost and capital cost with certain trade-off the measurement. In the point of view of trade-off theory, the company which has profitability will be safe in conducting the debt through debt because they can do the obligation towards the cost emerges from the activity of this fund, while for pecking order theory it is better for the company to use the advantage obtained to be retained earning in order to get safe funding.

The company which experiences funding surplus will have more choices in conducting the company fund because of the good financial condition. In 2017, Indonesia inexperienced general a surplus of the balance of payments, the capital transaction, and finance experienced a large surplus. Based on the data of BI (Bank of Indonesia), in the private sector Indonesia at the same time experiences the decrease on the usage of debt in the amount of 3.2 percent compared to the usage of debt in the private sector in 2016. The occurrence of surplus on the capital market and Indonesia finance followed by the decrease of debt in the private sector indicates that the private companies prefer to use the funding using the options beside debt such as the funding through the establishment of the share and internal funding in accordance with pecking order theory (Bank of Indonesia, 2018). The condition of the private sector in Indonesia in general shows that the companies experience surplus at the same time with the occurrence of the decrease in debt usage in the decision of company funding. Pecking order theory which has the view that the entity which experiences the funding surplus, better to use the surplus fund for the company fund and postpone the dividend share because having this option means having small risk compared to using debt. Myers (2001) states that the company which experiences funding surplus in the decision of its capital structure will choose 
to pay debt conducted the previous period and minimize the usage of its fund.

This research conducted re-examination on pecking order theory and trade-off theory on Indonesian companies in order to test the consistency of the implementation of pecking order theory and trade-off theory in Indonesian companies. The researcher combined determinants from the capital structure based on pecking order theory and trade-off theory which consists of profitability, sales growth, non-debt tax shield, and stability assets for tested at the company debt ratio which describes the proportion of the company capital structure. This research added funding surplus variable of the company to test the implementation of pecking order theory in Indonesian companies. Bhama, Jain, \& Yadav (2016) found out the results that Indian company is proven following pecking order theory in which the company surplus will decrease the company funding through debt and focus on the internal fund. The focus of this research is on the data of non-financial companies listed at Indonesia Stock Exchange (BEI) which experienced funding surplus in 2017 that at that time Indonesia also experienced surplus on the private sectors at the same time with the decrease on the debt use. Non-financial companies were used because they have different capital structure compared to the financial companies such as a bank, insurance, and credits which have different funding compared to non-financial companies until it can describe the condition in general of the companies in Indonesia in taking decision-related to the capital structure. The condition of the company which experiences surplus is chosen because it shows that the company has the good financial condition until it is expected that this research will get deeper result related to the theory of the capital structures, mainly pecking order theory in line with the model built by Shyam-Sunders \& Myers (1999). The period chosen was 2014-2017 in order to give the most up to date result in similar research.

The difference of this research is the examination towards the funding surplus variable on Indone- sian companies still never been done beforehand until it will add the most current reference in the field of the capital structure research. The selection of funding surplus variable is considered precise because the decrease of debt must be followed by the company funding which experienced surplus and by what happens in Indonesia in 2017.

This research finds the result that funding surplus has a positive effect on the usage of debt in the capital structure of the company. Profitability and tangibility assets hurt the capital structure of the company. This result is on the contrary with the theory which states that non-debt tax shield and sales growth do not affect the company capital structure. The research result obtained shows that Indonesia companies do not show consistency in the implementation of pecking order theory and trade-off theory in the practice of company capital structure in Indonesia.

\section{Hypotheses Development}

The company which has good profitability will certainly have various alternative in making a funding decision. In pecking order theory, the company which has high profitability tends to prioritize the funding through the internal of the company because the company finance is considered capable in financing the company fund. The profitability improvement will enable the company to strengthen better financial autonomy and will minimize the use of debt in its funding. Miglo (2016) states that heretofore pecking order theory is the most relevant theory to explain the correlation between profitability and the capital structure because, at the different financial condition, the company will always choose safe funding first.

The previously empirical research conducted by Tong \& Green (2005), Zhang \& Kanazaki (2007), Vasiliou, Eriotis, \& Daskalakis (2009), Chiang, Chen, \& Lam (2010), Hussainey \& Aljifri (2012), Benkraiem \& Gurau (2013), Sugianto (2013), Gomez, Rivas, \& Bolanos (2014), Chadha \& Sharma (2015), Serrasqueiro \& Caetano (2015), Haron (2016), and 


\section{Determinants of capital structures based on the Pecking Order Theory and Trade-off Theory}

Hotman Jefferson Simatupang, Lilik Purwanti, \& Endang Mardiati

Abdulla (2017), found out that profitability has a negative effect on the company capital structure. The negative effect between profitability and the capital structure means when the company profitability increases, then the proportion of the debt used in the capital structure will decrease because the company will prioritize the internal funding first. Based on this explanation, then the first hypothesis in this research is:

$\mathrm{H}_{1}$ : profitability has a negative effect on the capital structure

In the point of view of trade-off theory, nondebt tax shield is the determinant factor in the company funding decision. DeAngelo \& Masulis (1980) says that in the view of trade-off theory, the company that has high non-debt tax shield will use smaller debt in its funding decision compared to the company that has low non-debt tax shield because the assets come from the company itself, then owning a high level of non-debt tax shield will not grow the agency problem and do not have potency of distress financial occurrence for the company.

The previous research conducted by Gomez, Rivas, \& Bolanos (2014) found out that non-debt tax shield affects the capital structure. In the conducted research, non-debt tax shield has a negative effect on the capital structure. From this result, it shows that high non-debt tax shield will make the company tend to decrease the use of debt in their funding decision. The result of that research is in line with the research conducted by Wald (1999) which found out that nondebt tax shield has a negative effect on the capital structure. Based on the explanation above, then the second hypothesis in this research is:

$\mathrm{H}_{2}$ : non-debt tax shield has a negative effect on the capital structure

The sales growth which gets higher will also make the company ability better in facing and minimizing the business risk that it encounters included taking the funding decision in order to obtain the capital. In pecking order theory, it is explained that the higher the sales growth of the company, then the company must use more internal funding because the company has strong internal funding. Brigham \& Houston (2001) says that the company with relatively stable sales can be safer in obtaining funding through the company internal because it has a lower risk. Based on the explanation above, it can be concluded that sales growth affects the capital structure.

The previous empirical research conducted by Ganguli (2013) and Yazdanfar \& Öhman (2014) show that sales growth is one of the variables that affect the capital structure of the company. That research also shows that variable sales growth has a positive effect on the capital structure. From the result of that research, it indicates the higher the sales growth, then the company will safer in using the debt in obtaining the capital until the company capital structure can also be higher. Based on the explanation above, the hypothesis proposed is:

$\mathrm{H}_{3}$ : the sales growth has a negative effect on the capital structure

In the trade-off theory, it is explained that one of the guarantees which can be used to obtain a loan in the form of debt is tangibility asset. This theory also explains that the company with high tangibility assets growth will have a better opportunity to obtain the debt loan by using the tangibility assets as the guarantee (Kayo \& Kimura, 2010). Based on that explanation, it can be concluded that the growth of tangibility assets affects the capital structure.

The empirical research by Chiang, Chen, \& Lam (2010), Sugianto (2013) Chadha \& Sarma (2015), and Abdulla (2017) found out that tangibility assets affect the capital structure. The result of the research conducted shows that tangibility assets have a unidirectional relationship with the capital structure of the company. Based on this explanation, then the fourth hypothesis of this research is:

$\mathrm{H}_{4}$ : tangibility assets have a positive effect on the capital structure 
Pecking order theory assumes that the company which experiences surplus can use it to conduct the funding for the next period because the internal funding is considered as the most profitable fund compared to taking debt or establishing equity. The company with surplus fund tends to have a low level of debt compared to the company with the deficit (Myers, 2001). Bhama, Jain, \& Yadav (2016) states that the surplus company is easier in following pecking order theory compared to the deficit company because the deficit company needs to consider whether the funding decision taken can cover deficit they encounter.

The previous empirical research conducted by Bhama, Jain, \& Yadav (2016) found out that the company experiencing surplus has a low level of debt because it is covered by the surplus fund they have. That research is in line with the research conducted by Monica \& Pramest (2017) which found out that funding surplus has a negative effect on the capital structure. Based on the explanation above, then the fifth hypothesis of this research is:

$\mathrm{H}_{5}$ : funding surplus has a negative effect on the capital structure

\section{Method, Data, and Analysis}

This research employed causal-comparative research. According to Indriantoro \& Supomo (2011), causal-comparative research is the type of research with problem characteristics like causality relationship between two variables or more.
The population in this research were all nonfinancial companies listed at BEI in 2018. Related to taking the samples, this research used a purposive sampling method with criteria as shown in Table 1 .

This research used secondary data, in which the financial report data of non-financial companies that have been audited from the site www.idx.co.id. The main data used in this research covered financial position statement and income statement. Related to data collection, this research used documentation technique, such as by collecting the data, jotting down the data, and studying the secondary data in the form of a financial report of non-financial companies listed at BEI in 2014-2017.

The capital structure will be proxied by using a debt to equity ratio. Debt equity ratio is the comparison between the total debt and total earning before tax, amortization, and depreciation in a company. The usage of proxy debt to equity ratio represents the usage of debt and equity in the capital structure of the company. Proxy about this capital structure is used in the research by Boateng (2004), Eriotis, Vasiliou, \& Ventoura Neokosmidi (2007), Stretcher (2011), Hussainey \& Aljifri (2012). The formula of the capital structure is:

DER $=$ Total Debt $:$ Total Equity

Profitability is the size of company performance in its operational activities during one period. In this research, profitability is proxied with net income di-

Table 1. The Procedures for Selecting Samples

\begin{tabular}{lr}
\hline \multicolumn{1}{c}{ The Criteria for Selecting Samples } & Samples Per Year \\
\hline Non-financial companies listed at BEI in 2018 & 466 \\
Non-financial companies not listed at Indonesia Stock Exchange (BEI) during period & $(48)$ \\
$2014-2017$ accordingly. & $(140)$ \\
Non-financial companies experiencing deficit during the period 2014-2017 ** & $(124)$ \\
Non-financial companies by using foreign currency in the financial report. & 154 \\
Total samples used &
\end{tabular}

*total companies observed: $154 * 4$ years $=616$ observations

** companies experiencing deficit issued in the research samples so that the results describing the companies condition which experiences a surplus 


\section{Determinants of capital structures based on the Pecking Order Theory and Trade-off Theory}

Hotman Jefferson Simatupang, Lilik Purwanti, \& Endang Mardiati

vided with the total asset. Proxy about this sales growth is beforehand has been used in the research by Tong $\&$ Green (2005), Zhang \& Kanazaki (2007), Vasiliou, Eriotis, \& Daskalakis (2009), Hussainey \& Aljifri (2012), Sugianto (2013), and Serrasqueiro \& Caetano (2015).

Non-debt tax shield is another element beside debt interest payment which can be admitted as a tax deduction. DeAngelo \& Masulis (1980) states that depreciation and amortization can be used as the tax deduction, Indonesia also admits the existence of nondebt tax shield in the form of depreciation and amortization regulated in UU PPh No. 36 in 2008 Paragraph 6 , Article 1 . Non-debt tax shield is proxied by comparing the total number of amortization and depreciation in one period with the total assets. This proxy beforehand had been used in the research by Zhang \& Kanazaki (2007) and Gomez, Rivas, \& Bolanos (2014). The formula of non-debt tax shield is:

Non debt tax shield $=$ Amortization + Depreciation $:$ Total Asset

The sales growth is the description of the existence of a good change in the form of improvement or sales decrease which come from the profit obtained by a company. In this research, sales growth is proxied with the percentage of average annual growth in total sales (Robinson, 2009). Proxy about this sales growth beforehand had been used in the research by Ganguli (2013), Yazdanfar \& Öhman (2014), Alipour, Mohammadi, \& Derakhshan (2015), and Chakrabarti \& Chakrabarti (2018). The formula for sales growth is:

Sales Growth $=$ Sales $_{(t)}-$ Sales $_{(t-1)}:$ Sales $_{(t-1)}$
Tangibility is the standard of the permanent asset (tangible) measured from the comparison between the permanent asset and the total asset owned by a company. The permanent assets measured are property, plant, and equipment (PPE) divided with total assets. This proxy is used in the research by Chiang, Chen, \& Lam (2010) Sugianto (2013), Chadha \& Sarma (2015), and Abdulla (2017). The formula of tangibility assets is:

Tangibility Assets = PPE : Total Assets

Funding surplus shows the investment condition. Proxy from funding surplus (SUR) is operating cash flow (CF) diminished with investment cash flow. Investment cash flow is measured with dividend additions (Div), net investment (I), the portion of long term debt payment (R), and working capital change (ÄFDR). Operating cash flow is measured by adding earning after taxes, depreciation, amortization as mentioned by Shyam-Sunder \& Myers (1999). Net investment meant in this research is capital expenditure (CAPEX). The proxy of this research is by the proxy used in the research by Bhama, Jain, \& Yadav (2016).

The method of data analysis used was descriptive analysis and Linear Regression analysis with panel data. The statistical program to study the Panel Regression examination was Eviews version 9. Data panel are the combination between time series and cross-section. This decision related to the hypothesis of this research from the regression coefficient and the significance value ( $p$-value). The real level $(\alpha)$ used was 0.05 .

Table 2. The Result of Descriptive Analysis

\begin{tabular}{lcccccc}
\hline & DER & NDTS & Profitability & Sales & Surplus & Tangibility \\
\hline Mean & 1.136109 & 0.220688 & 0.064439 & 0.159646 & $2.16 \mathrm{E}+12$ & 0.350158 \\
Median & 0.783382 & 0.171250 & 0.052806 & 0.078695 & $5.45 \mathrm{E}+11$ & 0.312374 \\
Maximum & 13.54321 & 0.986358 & 0.526237 & 13.07398 & $8.24 \mathrm{E}+13$ & 0.946774 \\
Minimum & 0.574895 & 0.000000 & -0.868179 & -6.984133 & $9.27 \mathrm{E}+08$ & 0.000455 \\
Std. Dev. & 1.344905 & 0.191489 & 0.085443 & 0.919515 & $6.56 \mathrm{E}+12$ & 0.233825 \\
\hline
\end{tabular}

Note: Variable funding surplus measured with trillion units 


\section{Jurnal Keuangan dan Perbankan \\ Volume 23, Issue 1, January 2019: 84-102}

\section{Results}

\section{Descriptive analysis}

The descriptive analysis covers the calculation of the minimum value and maximum value, the average, and the standard deviation - the result of the descriptive analysis presented in Table 2.

The result of the descriptive analysis shows that the usage of debt in the capital structure of non-financial companies in Indonesia which experience surplus has the average score in the amount of 1.13 and are at range 0.57 until 13.54. The result obtained shows that Indonesia companies tend to do funding through debt higher compared to companies of India which have the average score in the amount of 0.59 (Bhama, Jain, \& Yadav, 2016).

Zhang \& Kanazaki (2007) obtained the result that Japan companies use debt in the funding lower compared to the companies from Indonesia and India with an average score of 0.108 . Indonesian companies have DER value with high variability which indicates that the mixture of the capital structure of Indonesian companies have various numbers, the same condition occurs in Japan in which the value of the debt usage in the capital structure of the company showing high variability. Other variables which have high variability are profitability, the sales growth, and the funding surplus.

\section{The result of Regression Analysis}

The examination was conducted by using Eviews 9.0 and obtained the result as presented in Table 3.

Table 3. Best Model Selection

\begin{tabular}{ll}
\hline \multicolumn{1}{c}{ Model Test } & \multicolumn{1}{c}{ Best Model } \\
\hline Uji Chow & Fix Effect Model \\
Uji Hausman & Random Effect Model \\
Uji LM & Random Effect model \\
\hline
\end{tabular}

The best model in this research is the random effect model. The estimation in random effect model based on general least square (GLS), until the examination of classic assumption can be ignored. The result of the analysis of the effect among the funding surplus, profitability, non-debt tax shield, tangibility, and the growth of the company towards the capital structure based on random effect model (LM test) can be seen through Table 4 .

The model built based on random effect model still has cross-sectional dependency because, at crosssection dependent test, all values of p-value are under 0.05 (Table 5). In order to overcome the cross-section dependency, the next coefficient estimation needs to be done based on white cross-section estimation (Table 6) until the model has been invulnerable towards the dependency infraction among cross sectionals.

Table 4. The Result of Selecting The Model (LM Test)

\begin{tabular}{lrcrc}
\hline \multicolumn{1}{c}{ Variable } & Coefficient & Std. Error & t-Statistic & Prob. \\
\hline C & 1.466234 & 0.142197 & 10.31127 & 0.0000 \\
PROFITABILITAS & -1.633348 & 0.489094 & -3.339541 & 0.0009 \\
NDTS & -0.175653 & 0.297280 & -0.590867 & 0.5548 \\
SALES & 0.000824 & 0.000748 & 1.101712 & 0.2710 \\
TANGIBILITY & -0.816807 & 0.223739 & -3.650717 & 0.0003 \\
SURPLUS & $3.81 \mathrm{E}-14$ & $1.14 \mathrm{E}-14$ & 3.347732 & 0.0009 \\
\hline
\end{tabular}

Table 5. Cross Section Dependent Test

\begin{tabular}{lccc}
\hline \multicolumn{1}{c}{ Test } & Statistic & d.f. & Prob. \\
\hline Breusch-Pagan LM & 19513.45 & 11781 & 0.0000 \\
Pesaran scaled LM & 50.37453 & & 0.0000 \\
Pesaran CD & 2.930572 & & 0.0034 \\
\hline
\end{tabular}




\section{Determinants of capital structures based on the Pecking Order Theory and Trade-off Theory \\ Hotman Jefferson Simatupang, Lilik Purwanti, \& Endang Mardiati}

Based on the hypothesis test conducted, it shows that the funding surplus variable has significance in the amount of 0.029 and coefficient value in the amount of 3.81. The result of the test shows that probability $<$ level of significance $(a=5$ percent $)$ which means funding surplus affects the capital structure. The test result shows that there is a positive effect between funding surplus and capital structure of the company which consistently also displayed in Table 7. Until it can be concluded that hypothesis 1 (funding surplus has a negative effect on the capital structure) is rejected.

The coefficient value of variable profitability is in the amount of -1.663 . In the table of $t$ statistical test results, also shows that the variable tax level has $\mathrm{t}$ significance in the amount of 0.000 . Because $t$ significance $<5$ percent $(0.000<0.05)$ then variable profitability has effect towards variable capital structure. The regression coefficient is negative $(-1.663)$ indicates that the higher the profitability causing the value of the debt usage in the company capital structure will decrease, the result obtained consistently in the same direction with the result of correlation test which obtained the result in the amount of -0.181 . Thus, it can be concluded that hypothesis 2 is accepted.
The results of the test show that the coefficient value of variable nondebt tax shield is in the amount of -0.175 . The results obtained have direction consistency on the result of the correlational test which obtained result -0.091 . In the table of $t$ statistical test result (Table 5.6) also shows that the variable nondebt tax shield has $t$ significance value in the amount of 0.5139 . Because $t$ significance $>5$ percent $(0.5139$ $>0.05)$, then variable non-debt tax shield does not have an effect towards variable the capital structure. Thus, it can be concluded that hypothesis 3 is rejected.

The hypothesis testing from the effect of tangibility assets towards the capital structure generates the coefficient value in the amount of -0.816 with probability in the amount of 0.000 . Variable tangibility assets have consistency direction with the correlational test (Table 7) with value in the amount of -0.812 . The result of that test shows a probability $<$ level of significance $(a=5$ percent). This means that there is significant influence partially of tangibility towards the capital structure until it can be concluded that hypothesis 4 is accepted.

Hypothesis test partially on the size of company sales growth towards the capital structure obtains the coefficient value in the amount of 0.000 with prob-

Table 6. White Cross Section Estimation

\begin{tabular}{lcccc}
\hline \multicolumn{1}{c}{ Variable } & Coefficient & Std. Error & t-Statistic & Prob. \\
\hline C & 1.466234 & 0.120026 & 12.21593 & 0.0000 \\
PROFITABILITAS & -1.633348 & 0.319294 & -5.115504 & 0.0000 \\
NDTS & -0.175653 & 0.268914 & -0.653194 & 0.5139 \\
SALES & 0.000824 & $7.45 \mathrm{E}-05$ & 11.06461 & 0.2215 \\
TANGIBILITY & -0.816807 & 0.109187 & -7.480797 & 0.0000 \\
SURPLUS & $3.81 \mathrm{E}-14$ & $2.51 \mathrm{E}-14$ & 1.518609 & 0.0294 \\
\hline
\end{tabular}

Table 7. Correlational Test

\begin{tabular}{|c|c|c|c|c|c|c|}
\hline & DER & NDTS & PROFIT & SALES & SURPLUS & TANGIBILITY \\
\hline$\overline{\mathrm{DER}}$ & 1.000000 & -0.091508 & -0.181083 & 0.034850 & 0.071721 & -0.081240 \\
\hline NDTS & -0.091508 & 1.000000 & -0.041659 & -0.078029 & 0.201348 & 0.518774 \\
\hline PROFITABILITAS & -0.181083 & -0.041659 & 1.000000 & 0.061254 & 0.132373 & -0.112974 \\
\hline SALES & 0.034850 & -0.078029 & 0.061254 & 1.000000 & 0.021402 & -0.086239 \\
\hline SURPLUS & 0.071721 & 0.201348 & 0.132373 & 0.021402 & 1.000000 & 0.081335 \\
\hline TANGIBILITY & -0.081240 & 0.518774 & -0.112974 & -0.086239 & 0.081335 & 1.000000 \\
\hline
\end{tabular}


ability in the amount of 0.2215 . The result of this test shows the probability $>$ level of significance $(a=5$ percent). This means there is no significant effect partially of company sales growth towards the capital structure. Thus, it can be concluded that hypothesis 5 is rejected.

\section{Discussion}

\section{The effect of funding surplus towards the capital structure}

The result of the test conducted shows that Indonesian companies which experience funding surplus prefer to do funding through debt compared to using their own funding surplus as the source of fund. Sjahrial (2014) states that trade-off theory has a view that the companies can conduct funding through debt as the motive to obtain advantage through tax, the funding through debt can be done until the limitation of the profit obtained has the same value with the cost that must be issued in that funding. Based on the result of the test conducted on the Indonesian companies, it can be concluded that the capital structure from the funding surplus of the company will focus on the usage of debt which means Indonesian companies follow trade-off theory. The usage of debt in the company which experiences surplus also can be interpreted if the company experiences funding surplus, it has the possibility to conduct business expansion until it needs additional capital from external party because the company will be safe in line with better financial condition of the company which describes the company business is in good condition.

\section{The effect of profitability towards the capital structure}

The result of the research conducted shows that the higher profitability of the company in Indonesia, then the usage of debt in its funding decision will be low, and otherwise, if the company experiences low profitability even experiencing disadvantage, then it will decide the funding through debt first.
The result of this research supports pecking order theory which states that the higher profitability of a company, then the company will tend to use internal funding. Internal funding is more prioritized by the company with the good financial condition because it has a lower risk compared to other funding decisions (Miglo, 2016). High profitability is considered making the company having good financial autonomy until the company can minimize the use of the external fund in its funding. The result of this research also proves that the implementation of pecking order theory as the most relevant theory in explaining the correlation between profitability and the capital structure of the companies in Indonesia. The result of the research obtained is in line with the research conducted by Tong \& Green (2005), Zhang \& Kanazaki (2007), Vasiliou, Eriotis, \& Daskalakis (2009), Chiang, Chen, \& Lam (2010), Hussainey \& Aljifri (2012), Benkraiem \& Gurau (2013), Gomez, Rivas, \& Bolanos (2014), Chadha \& Sharma (2015), Serrasqueiro \& Caetano (2015), Haron (2016), and Abdulla (2017), who also proved that profitability has contradictory relationship towards the improvement of usage debt in the capital structure.

\section{The effect of non-debt tax shield towards the capital structure}

The research result of this variable does not support the result of the previous research by Wald (1999) and Gomez, Rivas, \& Bolanos (2014) who found out that variable non-debt tax shield has a negative effect towards the capital structure of the company. This research found out the result in line with the research conducted by Karadeniz et al. (2009) and Haron (2016) who do not find the effect between non-debt tax shield and the capital structure. The result of this research shows that Indonesian companies do not prioritize the advantage obtained from the tax regulation about depreciation and amortization which can decrease the tax cost in determining the funding through debt. In line with pecking order theory which states that the company which conducts the funding 
through debt if the fund is from the internal of the company cannot cover the company operational because of the minimum information asymmetry that can cause risks fro the company, until the amount of non debt tax shield of the company will not influence the company funding decision because it relates to the operational activities of the company that must be overcome as soon as possible.

\section{The effect of tangibility assets towards the capital structure}

The results of the research conducted show that tangibility assets are a determinant factor in the funding decision of Indonesia companies. The existence of permanent assets as the guarantee in conducting the funding through debt has significant impact towards the company decision in determining the capital structure as elaborated by trade-off theory which states that the company which has high permanent assets will be safer in conducting the funding through debt because the permanent assets can be made as guarantee in doing the loan. The results of the research conducted are in line with the research by Amidu (2007), Al-Najjar \& Hussainey (2011), and Serghiescu \& Vaidean (2014) who prove that there is effect between tangibility assets and the capital structure of the company.

\section{The effect of company sales growth towards the capital structure}

In hypothesis 5, it is elaborated that sales growth does not have a positive effect on the capital struc- ture. This hypothesis is not supported by the research results. Variable sales growth has significant value in the amount of 0.2215 , and positive direction showed by the regression coefficient direction from this research. The consistent research results also have been obtained through robustness test which does not find out the effect between sales growth and the capital structure.

\section{Robustness Test}

Robustness test is conducted to examine the validity of research results. Based on the robustness test, it obtains the result that variable profitability has a coefficient in the amount of -4.02 with probability in the amount of 0.00 . From the result of the test, it is found out that profitability has a negative effect towards the capital structure, the result of the test is consistent with the result of the hypothesis test (t-test). Variable funding surplus has a coefficient in the amount of 0.05 with probability in the amount of 0.00 which means variable funding surplus has a negative effect towards the capital structure of the company consistent with the result of the hypothesis test. Variable tangibility has a coefficient in the amount of 0.44 with probability in the amount of 0.00 which means variable tangibility has a negative effect on the capital structure consistent with the result of the hypothesis test.

This research implies pecking order theory and trade-off theory related to the company funding decision. Profitability is one of the determinant factors in taking the company decision related to funding. The high company profitability will make the company focus on funding through internal funding first until it decreases the use of debt as the company funding

Table 8. The Result of Robustness Test (M-estimation)

\begin{tabular}{lrcrc}
\hline \multicolumn{1}{c}{ Variable } & Coefficient & Std. Error & z-Statistic & Prob. \\
\hline NDTS & 0.076165 & 0.190561 & 0.399690 & 0.6894 \\
PROFITABILITY & -4.024486 & 0.416394 & -9.665099 & 0.0000 \\
SALES & 0.028689 & 0.032370 & 0.886264 & 0.3755 \\
SURPLUS & 0.054271 & 0.016925 & 3.206610 & 0.0013 \\
TANGIBILITY & -0.446130 & 0.158455 & -2.815496 & 0.0049 \\
C & -0.152263 & 0.460160 & -0.330891 & 0.7407 \\
\hline
\end{tabular}


sources. Tangibility assets are also as a determinant factor of the capital structure like elaborated by pecking order theory that the company which has permanent assets in big number better conduct funding through the internal of the company, and conducts external funding (establishing the share and debt) when the internal resources cannot fulfill the company funding needs.

Pecking order theory fails in explaining the direction of variable funding surplus towards the decision of funding in Indonesia. Indonesia companies tend to conduct funding through debt when experiencing a funding surplus. Funding surplus at Indonesia companies follows the criteria from the trade-off the theory that the company in good financial condition will be safe in conducting funding through debt because tradeoff between the cost issued and advantages can be achieved.

This research gives empirical evidence that the company management which has funding surplus can consider the funding through debt because of owning good financial condition, beside that the company also can obtain advantages from tax shield if conducting funding through debt. This research also gives empirical evidence that the company will choose to focus on conducting internal funding if having a big number of permanent assets. By having a big number of permanent assets, it will make the company safe in conducting internal fund because it describes that the company is in good financial condition. Company profitability can become the company funding source until the management can consider the usage of profitability obtained as the company funding sources because internal fund must be prioritized considering there is no agency cost must be issued and low risk compared to external fund.

\section{Conclusion, Limitations, and Suggestions Conclusion}

Based on the results of this research, then it can be concluded that there is no correlation between non-debt tax shield towards the capital structure. The research result which shows that Indonesia companies conduct funding through debt does not consider the existence of a tax shield which is an advantage for the companies. However, it more prioritizes on the needs of the company operations. Based on the results of this research, then it can be concluded that there is no correlation between sales growth towards the capital structure. The research result shows that the company does not consider the sales growth as the determinant factor in its capital structure. There is a unidirectional relationship between funding surplus towards the capital structure. The research results show that the higher the funding surplus of the company, then it causes the higher usage of debt in the capital structure of the company. This research finds out the result that tangibility assets correlate with the decision of company capital structure. The result of this research shows that Indonesia companies conduct funding based on their internal needs and utilize the ability of tangibility assets as the guarantee in conducting funding through loans. There is a contradictory relationship between profitability towards the capital structure. The result of this research shows that the higher profitability of the company, then it will cause the lower the usage of debt in the capital structure of the company.

Thoroughly it can be concluded that tangibility assets, funding surplus, and profitability are the determinant factors of the capital structure while non-debt tax shield and sales growth are not determinant factors of the capital structure in Indonesia companies. The information obtained from this research can be used as the reference for the next research and the companies, they can use it as consideration in taking funding decision.

\section{Limitations and suggestions}

This research has not been successful yet in proving that sales growth and non-debt tax shield is determinant of the capital structure. The next research can consider using different samples and proxy to obtain better results than this research. This research only fo- 


\section{Determinants of capital structures based on the Pecking Order Theory and Trade-off Theory}

Hotman Jefferson Simatupang, Lilik Purwanti, \& Endang Mardiati

cused on the correlation between the capital structure and funding surplus from the model built by Shyamsunders \& Myers (1999). The future researcher can add variable debt redemption in order to interpret this research thoroughly at the model built by Shyam-Sunders \& Myers (1999).

\section{References}

Abdulla, Y. (2017). Capital structure in a tax-free economy: evidence from UAE. International Journal of Islamic and Middle Eastern Finance and Management, 10(1), 102-116. https://doi.org/10.1108/IMEFM-11-2015-0144

Alipour, M., Mohammadi, M. F. S., \& Derakhshan, H. (2015). Determinants of capital structure: An empirical study of firms in Iran. International Journal of Law and Management, 57(1), 53 - 83. https://doi.org/10.1108/IJLMA-012013-0004

Al-Najjar, B., \& Hussainey, K. (2009). The association between dividend payout and outside directorships. Journal of Applied Accounting, 10(1), 4-19

Amidu, M. (2007). Determinants of capital structure of banks in Ghana: An empirical approach. Baltic Journal of Management, 2(1), 67-79. https://doi.org/10.1108/17465260710720255

Bhama, V., Jain, P. K., \& Yadav, S. S. (2016). Testing the pecking order theory of deficit and surplus firms: Indian evidence. International Journal of Managerial Finance, 12(3), 335-350. https://doi.org/10.1108/IJMF-06-20140095

Benkraiem, R., \& Gurau, C. (2013). How do corporate characteristics affect capital structure decisions of French SMEs? International Journal of Entrepreneurial Behavior \& Research, 19(2), 149-164. https://doi.org/10.1108/ 13552551311310356

Boateng, A. (2004). Determinants of capital structure: Evidence from international joint ventures in Ghana. International Journal of Social Economics, 31(1/2), 56-66. https://doi.org/10.1108/03068290410515411

Brigham, E. F., \& Houston, J. F. (2001). Manajemen Keuangan. Edisi Kedelapan. Jakarta: Erlangga.

Chadha, S., \& Sharma, A. (2015). Determinants of capital structure: An empirical evaluation from India. Journal of Advances in Management Research, 12(1), 3-14. https://doi.org/10.1108/JAMR-08-2014-0051

Chakrabarti, A., \& Chakrabarti, A. (2018). The capital structure puzzle - Evidence from Indian energy sector. International Journal of Energy Sector Management, https://doi.org/10.1108/IJESM-03-2018-0001.

Chiang, Y H., Cheng, E. W. L., \& Lam, P. T. I. (2010). Epistemology of capital structure decisions by building contractors in Hong Kong. Construction Innovation, 10(3), 329-345. https://doi.org/10.1108/14714171011060105

DeAngelo, H., \& Masulis, R. (1980). Optimal capital structure under corporate and personal taxation. Journal of Financial Economics, 8(1), 3-29. https://doi.org/10.1016/0304-405X(80)90019-7

Eriotis, N., Vasiliou, D., \& Ventoura Neokosmidi, Z. (2007). How firm characteristics affect capital structure: An empirical study. Managerial Finance, 33(5), 321-331. https://doi.org/10.1108/03074350710739605

Frank, M., \& Goyal, V. (2003). Testing the pecking order theory of capital structure. Journal of Financial Economics, 67(2), 217-248. https://doi.org/10.1016/S0304-405X(02)00252-0

Ganguli, S. (2013). Capital structure - Does ownership structure matter? Theory and Indian evidence. Studies in Economics and Finance, 30(1), 56-72. https://doi.org/10.1108/10867371311300982

Gomez, G., Rivas, A., \& Bolaños, E. (2014). The determinants of capital structure in Peru. Academia Revista Latinoamericana de Administración, 27(3), 341-354. https://doi.org/10.1108/ARLA-01-2014-0007

Haron, R. (2016). Do Indonesian firms practice target capital structure? A dynamic approach. Journal of Asia Business Studies, 10(3), 318-334. https://doi.org/10.1108/JABS-07-2015-0100 
Jurnal Keuangan dan Perbankan

Volume 23, Issue 1, January 2019: 84-102

Hussainey, K., \& Aljifri, K. (2012). Corporate governance mechanisms and capital structure in UAE. Journal of Applied Accounting Research, 13(2), 145-160. https://doi.org/10.1108/09675421211254849

Indriantoro, N., \& Supomo, B. (2011). Metodologi Penelitian Bisnis untuk Akuntansi dan Manajemen. Edisi Pertama. Yogyakarta: BPFE.

Karadeniz, E., Kandir, S., Balcilar, M., \& Onal, Y. (2009). Determinants of capital structure: Evidence from Turkish lodging companies. International Journal of Contemporary Hospitality Management, 21(5), 594-609. https:// doi.org/10.1108/09596110910967827

Kayo, E. K., \& Kimura, H. (2010). Hierarchical determinants of capital structure. Journal of Banking \& Finance, 35(2), 358-371. https://doi.org/10.1016/j.jbankfin.2010.08.015

Miglo, A. (2016). Capital Structure in Modern World. Ontario: Springer Nature.

Monica, J., \& Pramest, M. (2017). Pengujian Pecking Order Theory terhadap perusahaan surplus non-keuangan di Bursa Efek Indonesia. Jurnal Manajemen Teknologi, 16(2), 186-197. http://dx.doi.org/10.12695/jmt.2017.16.2.6

Myers, S. C. (2001). Capital structure. The Journal of Economic Perspectives, 15(2), 81-102. http://dx.doi.org/10.1257/ jep.15.2.81

Robinson, T. (2009). International Financial Management Analysis: Investment series. Hoboken, New Jersey: John Wiley \& Sons, Inc.

Ross, S., \& Westerfield, R. (2008). Modern Financial Management. Eight Edition. New York: Mc Graw-Hill Companies.

Sergieschu, L., \& Vaidean, V-L. (2014). Determinant factors of the capital structure of a firm - An empirical analysis. Procedia Economics and Finance, 15, 1447-1457. https://doi.org/10.1016/s2212-5671(14)00610-8

Serrasqueiro, Z., \& Caetano, A. (2015). Trade-off theory versus pecking order theory: Capital structure decisions in a peripheral region of Portugal. Journal of Business Economics and Management, 16(2), 445-466. https://doi.org/ 10.3846/16111699.2012.744344

Sjahrial, D. (2014). Manajemen Keuangan Lanjutan. Edisi Revisi. Jakarta: Mitra Wacana Media.

Stretcher, R., \& Johnson, S. (2011). Capital structure: Professional management guidance. Managerial Finance, 37(8), 788-804. https:/doi.org/10.1108/03074351111146229

Sugianto, H. (2013). Analisis determinan struktur modal berdasarkan pecking order theory pada perusahaan manufaktur yang terdaftar di BEI periode 2007-2011. Tesis. Universitas Indonesia.

Shyam-Sunder, L., \& Myers, S. C. (1999). Testing static trade-off theory against pecking order model of capital structure. Journal Financial Economics, 51(2), 219-244. https://doi.org/10.3386/w4722

Tong, G., \& Green, C. (2005). Pecking order or trade-off hypothesis? Evidence on the capital structure of Chinese companies. Applied Economics, 37(19), 2179-2189. https://doi.org/10.1080/00036840500319873

Vasiliou, D., Eriotis, N., \& Daskalakis, N. (2009). Testing the pecking order theory: The importance of methodology. Qualitative Research in Financial Markets, 1(2), 85-96. https://doi.org/10.1108/17554170910975900

Wald, J. (1999). How firm characteristics affect capital structure: An international comparison. Journal of Financial Research, 22(2), 161-87. https://doi.org/10.1111/j.1475-6803.1999.tb00721.x

Yazdanfar, D., \& Öhman, P. (2015). The impact of credit supply on sales growth: Swedish evidence. International Journal of Managerial Finance, 11(3), 329-340. https://doi.org/10.1108/IJMF-07-2014-0110

Zhang, R., \& Kanazaki, Y. (2007). Testing static trade-off against pecking order models of capital structure in Japanese firms. International Journal of Accounting \& Information Management, 15(2), 24-36. https://doi.org/10.1108/ 18347640710837335 